\title{
Studi Perbandingan Jumlah Plasmodium Malaria Menggunakan Variasi Volume Di Laboratorium RSUD dr. H. Chasan Boesoirie Ternate
}

\author{
Rony Puasa \\ Prodi D.III Analis Kesehatan Poltekkes Kemenkes Ternate
}

\begin{abstract}
Abstrak
Pemeriksaan malaria yang merupakan Gold Standart adalah dengan menggunakan mikroskop. Dignosa malaria secara mikroskopis dapat dilakukan dua cara yaitu dengan menghitung jumlah Plasmodium secara semikuantitatif dan kuantitatif. Cara kuantitatif dilakukan dengan menghitung jumlah Plasmodium malaria bersamaan dengan menghitung jumlah leukosit, bila jumlah Plasmodium telah mencapai 100 sel dan leukosit telah mencapai 200 maka dihentikan, bila Plasmodium belum mencapai 100 sel maka leukosit dihitung hingga mencapai 500 sel leukosit. Volume sampel darah yang digunakan untuk pembuatan sediaan darah tebal adalah $6 \mu \mathrm{l}, 10 \mu \mathrm{l}, 16 \mu \mathrm{l}$ dan $20 \mu \mathrm{l}$. Tujuan penelitian ini adalah untuk mengetahui perbedaan jumlah Plasmodium malaria dari setiap variasi volume sampel darah tebal. Metode penelitian yang digunakan adalah deskriptif dengan jenis penelitian Studi Perbandingan (Comparatif Study) dan dianalisa menggunakan Uji Anova. Jumlah sampel 1 (satu), kemudian sampel tesebut di multipikasi menjadi 120 sediaan darah. Hasil penelitian menggunakan analisa statistik dengan derajat kepercayaan $95 \%$ didapatkan nilai signifikan setiap variasi volume baik $10 \mu 1,16 \mu 1$ dan $20 \mu 1$ pada sediaan darah tebal dengan nilai $0.000<0.005$, maka hipotesa Ha diterima. Kesimpulan adalah ada perbedaan yang signifikan antara lama volume standar $6 \mu 1$ dengan variasi volume $10 \mu 1$, $16 \mu \mathrm{l}$ dan $20 \mu 1$.
\end{abstract}

Kata Kunci : Plasmodium, malaria, variasi volume

\section{Comparison Study Of The Plasmodium Malaria Total Using Volume Variation In Laboratory of RSUD dr. H. Chasan Boesoirie Ternate}

\begin{abstract}
Gold Standard malaria examination is by using a microscope. Microscopic malignancy can be done in two ways, namely by calculating the amount of Plasmodium in a quantitative and semi-quantitative manner. Quantitative method is done by calculating the amount of Plasmodium malaria together with calculating the number of leukocytes, if the amount of Plasmodium has reached 100 cells and leukocytes have reached 200 then stopped, if Plasmodium has not reached 100 cells then leukocytes are counted to reach 500 leukocyte cells. The volume of

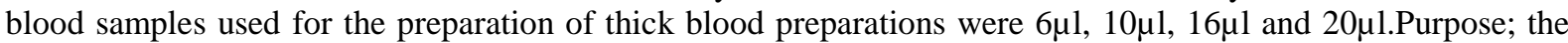
purpose of this study was to determine the differences in the amount of Plasmodium malaria from each variation in the volume of thick blood samples. Method; the research used was descriptive with the type of Comparative Study and analyzed using Anova Test. This test is used to compare one population average with one other population average. The number of samples is 1 (one), then the sample is multiplied into 120 blood preparations. Results ; From the results of the study obtained using statistical analysis with a 95\% confidence level obtained significant values for each volume variation of either $10 \mu 1,16 \mu 1$ and $20 \mu 1$ on thick blood preparations with a value of $0.000<0.005$, then the hypothesis $\mathrm{Ha}$ is accepted. This shows there is a difference between the variations in volume of blood samples in thick blood preparations with a standard volume of $6 \mu 1$. Conclusion; There is a significant difference between the standard volume length of $6 \mu 1$ and the volume variations of $10 \mu 1$, $16 \mu 1$ and $20 \mu 1$.
\end{abstract}

Keywords : Plasmodium, malaria, volume variation

Korespondensi: Roni Puasa, Prodi D.III Analis Kesehatan Politeknik Kesehatan Kemenkes Ternate, Poltekkes Ternate, Jl. Cempaka, Tanah Tinggi Bar., Ternate Sel., Kota Ternate, Maluku Utara, e-mail rony_yani@yahoo.co.id 


\section{Pendahuluan}

Malaria adalah penyakit yang mengancam jiwa manusia disebabkan oleh parasit Plasmodium yang ditularkan pada manusia melalui gigitan nyamuk Anopheles betina. Nyamuk ini bertindak sebagai vektor dan akan menggigit manusia mulai dari malam hari (dusk) sampai fajar (dawn). Gejala dari penyakit malaria dapat berupa demam, yang terjadi tujuh hari sampai dua minggu. Gejala lain yang ditemukan pada penderita adalah sakit kepala, menggigil, dan muntah-muntah, jika tidak diobati dalam waktu 24 jam parasit akan berkembang cepat menjadi penyakit malaria yang berat bahkan dapat menimbulkan kematian, (Soedarto, 2009).

Salah satu tekhnik diagnosa malaria yang paling diyakini dan dapat menemukan jenis serta stadium dari parasit Plasmodium adalah peme- riksaan mikroskopis. Pemeriksaan mikroskopis merupakan Gold Standart untuk identifikasi malaria. Cara pemeriksaan ini merupakan peme- riksaan yang dianjurkan oleh World Health Organization (WHO) dan Kementrian Kesehatan Republik Indonesia. Pemeriksaan mikroskopis malaria dapat dilakukan diseluruh jenjang pelayanan kesehatan, mulai dari pelayanan dasar sampai dengan pelayanan rujukan. Peme- riksaan malaria secara mikroskopis sangat membantu masyarakat karena menggunakan biaya yang murah, (Direktur Jenderal PP dan PL Kementrian Kesehatan, 2014).

Dignosa malaria secara mikroskopis dapat dilakukan dua cara yaitu dengan menghitung jumlah Plasmodium secara semikuantitatif dan kuantitatif. Cara kuantitatif dilakukan dengan menghitung jumlah Plasmodium malaria bersamaan dengan menghitung jumlah leukosit, bila jumlah leukosit telah mencapai 200 maka perhitungan Plasmodium dihentikan dan diban- dingkan terhadap jumlah leukosit normal $(8000 / \mu \mathrm{l})$. Perhitungan dilakukan dalam sediaan darah tebal, (Rosdiana Safar, 2010). Cara perhitungan jumlah Plasmodium ini sementara digalakan oleh Kementrian Kesehatan di seluruh sarana pelayanan kesehatan, dapat dilihat dengan dilakukan pelatihan mikroskopis malaria bagi tenaga laboratorium. Sebelum dilakukan pe-r hitungan terhadap Plasmodium malaria, sampel darah dibuat dalam dua jenis yaitu sediaan darah tipis dan darah tebal. Darah tipis menggunakan volume $2 \mu \mathrm{l}$ sedangkan darah tebal menggunakan volume darah $6 \mu \mathrm{l}$. Volume ini merupakan standar yang ditetapkan oleh
Kementrian Kesehatan dan WHO, diharapkan dapat digunakan sarana pelayanan kesehatan, (Direktur Jenderal PP dan PL Kementrian Kesehatan, 2014).

Penggunaan darah untuk sediaan tebal malaria sebanyak 2-3 tetes yang diperkirakan setara dengan $6 \mu$ l kemungkinan akan tidak akurat, hal ini dapat disebabkan oleh karena volume 1 tetes ukuran mikro, bila disetarakan sama dengan $16 \mu l$, sedangkan 1 tetes ukuran makro disetarakan dengan $20 \mu \mathrm{l}$, (Arny, 2019) maka bila menggunakan tetesan akan berbeda jauh dengan menggunakan mikropipet, dimana untuk pembuatan darah tebal malaria membutuhkan volume $6 \mu$ l.

Dengan melihat perbedaan volume darah yang digunakan untuk pemeriksaan malaria bila tidak menggunakan mikropipet dan hanya mengguna kan darah 2-3, dimana 1 tetes setara dengan $16-20 \mu \mathrm{l}$, maka hal ini yang membuat peneliti berkeinginan melakukan penelitian dengan cara menghitung jumlah Plasmodium malaria dan leukosit pada setiap variasi volume.

\section{Metode}

Metode penelitian ini adalah deskriptif dengan jenis penelitian Studi Perbandingan (Comparatif Study), hasilnya diuji menggunakan Uji Anova. Uji ini digunakan untuk membandingkan satu rata-rata populasi dengan satu rata-rata populasi yang lain, (Suseno Bimo, 2010). Pada penelitian ini ditelaah adakah perbedaan antara jumlah Plasmodium malaria yang terdapat pada sediaan darah tebal dengan volume $6 \mu$ l terhadap setiap variasi volume ; $10 \mu \mathrm{l}, 16 \mu \mathrm{l}$ dan $20 \mu \mathrm{l}$.

Populasi dalam penelitian ini adalah pasien malaria falcifarum positif yang telah diperiksa di Laboratorium RSUD Dr.H.Chasan Boesoirie Ternate

Sampel yang digunakan pada penelitian ini adalah darah pasien malaria falcifarum positif. Jumlah subjek dari penelitian ini adalah 1 orang pasien atau penderita positif malaria. Dari sampel darah subjek di multipikasi menjadi 120 sediaan darah tebal yang diwarnai dengan Giemsa dengan jumlah setiap variasi volume sebagai berikut ;

1) $6 \mu \mathrm{l}$ sebanyak 30 sediaan

2) $10 \mu \mathrm{l}$ sebanyak 30 sediaan

3) $16 \mu$ l sebanyak 30 sediaan

4) $20 \mu \mathrm{l}$ sebanyak 30 sediaan

Adapun kriteria sampel dalam penelitian ini meliputi kriteria inklusi yaitu Plasmodium falcifarum stadium tropozoit dan Plasmodium 
falcifarum pada sediaan darah tebal. Kriteria eksklusi yaitu darah pasien yang lisis, darah pasien yang telah mengalami pembekuan dan Plasmodium falcifarum dengan stadium gametosit

\section{Hasil}

Data penelitian diperoleh melalui perhitungan jumlah Plasmodium falcifarum pada sediaan darah tebal di Laboratorium Terpadu Poltekkes Kemenkes Ternate yang dikumpulkan, maka data tersebut disajikan secara deskriptif dan analitik dalam tabel tabel sebagai berikut :

1) Analisa Univariat

Tabel 1. Hasil Perhitungan Plamodium malaria dari Tetes Darah Tebal Volume $6 \mu 1$

\begin{tabular}{|c|c|c|c|}
\hline \multirow{2}{*}{ Kode } & \multicolumn{2}{|c|}{ Jumlah } & \multirow{2}{*}{$\begin{array}{c}\text { Jumlah } \\
\text { Plasmodium } \\
\text { ( } \mu \mathrm{l} \text { darah) }\end{array}$} \\
\hline & Plasmodium & Leukosit & \\
\hline $1 / 6$ & 24 & 505 & 380 \\
\hline $2 / 6$ & 28 & 506 & 443 \\
\hline $3 / 6$ & 23 & 504 & 365 \\
\hline $4 / 6$ & 31 & 501 & 495 \\
\hline $5 / 6$ & 25 & 503 & 398 \\
\hline $6 / 6$ & 22 & 503 & 350 \\
\hline $7 / 6$ & 22 & 505 & 349 \\
\hline $8 / 6$ & 22 & 502 & 351 \\
\hline $9 / 6$ & 17 & 504 & 270 \\
\hline $10 / 6$ & 24 & 501 & 383 \\
\hline $11 / 6$ & 30 & 506 & 474 \\
\hline $12 / 6$ & 32 & 503 & 509 \\
\hline $13 / 6$ & 30 & 500 & 480 \\
\hline $14 / 6$ & 28 & 506 & 443 \\
\hline $15 / 6$ & 28 & 503 & 445 \\
\hline $16 / 6$ & 30 & 503 & 477 \\
\hline $17 / 6$ & 29 & 505 & 459 \\
\hline $18 / 6$ & 22 & 505 & 349 \\
\hline $19 / 6$ & 16 & 501 & 255 \\
\hline $20 / 6$ & 23 & 503 & 366 \\
\hline $21 / 6$ & 23 & 501 & 367 \\
\hline $22 / 6$ & 24 & 509 & 377 \\
\hline $23 / 6$ & 19 & 503 & 302 \\
\hline $24 / 6$ & 24 & 509 & 377 \\
\hline $25 / 6$ & 21 & 500 & 464 \\
\hline $26 / 6$ & 29 & 502 & 335 \\
\hline $27 / 6$ & 20 & 505 & 317 \\
\hline $28 / 6$ & 26 & 503 & 414 \\
\hline $29 / 6$ & 20 & 502 & 319 \\
\hline $30 / 6$ & 30 & 505 & 475 \\
\hline
\end{tabular}

Berdasarkan tabel 1 diketahui kepadatan Plasmodium malaria tertinggi yaitu ; 509/ $\mu 1$ darah, terdapat pada sediaan darah dengan nomor kode $12 / 6$, sedangkan terendah dengan jumlah ; $255 / \mu$ darah pada seiaan darah nomor kode 19/6. Jumlah rata-rata Plasmodium malaria yang diperoleh pada tetes darah tebal dengan volume sampel $6 \mu 1$ adalah $393 / \mu 1$ darah.

Tabel 2. Distribusi Hasil Perhitungan Plamodium malaria dari Tetes Darah Tebal Volume $10 \mu 1$

\begin{tabular}{|c|c|c|c|}
\hline \multirow{2}{*}{ Kode } & \multicolumn{2}{|c|}{ Jumlah } & \multirow{2}{*}{$\begin{array}{c}\text { Jumlah } \\
\text { Plasmodium } \\
\text { ( } \mu \mathrm{l} \text { darah) }\end{array}$} \\
\hline & Plasmodium & Leukosit & \\
\hline $1 / 10$ & 28 & 509 & 440 \\
\hline $2 / 10$ & 24 & 505 & 380 \\
\hline $3 / 10$ & 35 & 503 & 557 \\
\hline $4 / 10$ & 22 & 509 & 346 \\
\hline $5 / 10$ & 28 & 502 & 446 \\
\hline $6 / 10$ & 27 & 508 & 425 \\
\hline $7 / 10$ & 27 & 503 & 429 \\
\hline $8 / 10$ & 40 & 505 & 634 \\
\hline $9 / 10$ & 37 & 506 & 585 \\
\hline $10 / 10$ & 32 & 506 & 506 \\
\hline $11 / 10$ & 34 & 503 & 541 \\
\hline $12 / 10$ & 24 & 503 & 382 \\
\hline $13 / 10$ & 34 & 506 & 538 \\
\hline $14 / 10$ & 33 & 504 & 524 \\
\hline $15 / 10$ & 23 & 501 & 367 \\
\hline $16 / 10$ & 30 & 505 & 475 \\
\hline $17 / 10$ & 32 & 503 & 509 \\
\hline $18 / 10$ & 27 & 503 & 429 \\
\hline $19 / 10$ & 36 & 505 & 570 \\
\hline $20 / 10$ & 41 & 503 & 652 \\
\hline $21 / 10$ & 36 & 504 & 571 \\
\hline $22 / 10$ & 34 & 507 & 536 \\
\hline $23 / 10$ & 31 & 502 & 494 \\
\hline $24 / 10$ & 40 & 505 & 634 \\
\hline $25 / 10$ & 32 & 501 & 511 \\
\hline $26 / 10$ & 28 & 507 & 442 \\
\hline $27 / 10$ & 32 & 502 & 510 \\
\hline $28 / 10$ & 23 & 502 & 367 \\
\hline $29 / 10$ & 35 & 503 & 557 \\
\hline $30 / 10$ & 40 & 503 & 636 \\
\hline Rata-r & ta Plasmodiur & $\mu$ l darah & 500 \\
\hline
\end{tabular}

Berdasarkan tabel 2, diketahui kepadatan Plasmodiummalaria tertinggi yaitu ;652/ $\mu \mathrm{l}$ darah, pada sediaan darah dengan nomor kode 20/10, sedangkan terendah dengan jumlah; 346/ $\mu 1$ darah pada sediaan darah dengan nomor kode 4/10. Jumlah rata-rata Plasmodium malaria yang diperoleh pada tetes 
darah tebal dengan volume sampel $10 \mu$ adalah $500 / \mu 1$ darah.

Tabel 3. Distribusi Hasil Perhitungan Plamodium malariadari Tetes Darah Tebal Volume 16 $\mu \mathrm{l}$

\begin{tabular}{|c|c|c|c|}
\hline \multirow{2}{*}{ Kode } & \multicolumn{2}{|c|}{ Jumlah yang dihitung } & \multirow{2}{*}{$\begin{array}{c}\text { Jumlah } \\
\text { Plasmodium } \\
\text { ( } \mu \text { l darah) }\end{array}$} \\
\hline & Plasmodium & Leukosit & \\
\hline $1 / 16$ & 48 & 500 & 768 \\
\hline $2 / 16$ & 34 & 503 & 541 \\
\hline $3 / 16$ & 37 & 503 & 588 \\
\hline $4 / 16$ & 33 & 503 & 525 \\
\hline $5 / 16$ & 35 & 505 & 554 \\
\hline $6 / 16$ & 39 & 505 & 618 \\
\hline $7 / 16$ & 33 & 502 & 526 \\
\hline $8 / 16$ & 32 & 507 & 505 \\
\hline $9 / 16$ & 38 & 501 & 607 \\
\hline $10 / 16$ & 30 & 508 & 472 \\
\hline $11 / 16$ & 41 & 506 & 648 \\
\hline $12 / 16$ & 36 & 502 & 574 \\
\hline $13 / 16$ & 35 & 506 & 553 \\
\hline $14 / 16$ & 31 & 507 & 489 \\
\hline $15 / 16$ & 30 & 504 & 472 \\
\hline $16 / 16$ & 32 & 504 & 508 \\
\hline $17 / 16$ & 36 & 502 & 574 \\
\hline $18 / 16$ & 36 & 500 & 576 \\
\hline $19 / 16$ & 34 & 503 & 541 \\
\hline $20 / 16$ & 26 & 501 & 415 \\
\hline $21 / 16$ & 34 & 508 & 535 \\
\hline $22 / 16$ & 38 & 504 & 603 \\
\hline $23 / 16$ & 32 & 500 & 512 \\
\hline $24 / 16$ & 30 & 508 & 472 \\
\hline $25 / 16$ & 31 & 504 & 492 \\
\hline $26 / 16$ & 30 & 505 & 475 \\
\hline $27 / 16$ & 30 & 504 & 476 \\
\hline $28 / 16$ & 33 & 500 & 528 \\
\hline $29 / 16$ & 29 & 501 & 463 \\
\hline $30 / 16$ & 30 & 504 & 476 \\
\hline \multicolumn{3}{|c|}{ Rata-rata Plasmodium/ $\mu \mathrm{l}$ darah } & 636 \\
\hline
\end{tabular}

Berdasarkan tabel 3, diketahui kepadatan Plasmodium malaria tertinggi yaitu 768/ $\mu 1$ darah, pada sediaan darah dengan nomor kode $1 / 16$, sedangkan terendah dengan jumlah $415 / \mu 1$ darah pada sediaan darah dengan nomor kode 20/16. Jumlah rata-rata Plasmodium malaria yang diperoleh pada tetes darah tebal dengan volume sampel $16 \mu 1$ adalah $636 / \mu 1$ darah.
Tabel 4. Distribusi Hasil Perhitungan Plamodium malaria dari Tetes Darah Tebal Volume $20 \mu 1$

\begin{tabular}{|c|c|c|c|}
\hline \multirow{2}{*}{ Kode } & \multicolumn{2}{|c|}{ Jumlah yang dihitung } & \multirow{2}{*}{$\begin{array}{c}\text { Jumlah } \\
\text { Plasmodium } \\
\text { ( } \mu \text { l darah) }\end{array}$} \\
\hline & Plasmodium & Leukosit & \\
\hline $1 / 20$ & 36 & 504 & 571 \\
\hline $2 / 20$ & 29 & 507 & 458 \\
\hline $3 / 20$ & 31 & 508 & 488 \\
\hline $4 / 20$ & 35 & 503 & 557 \\
\hline $5 / 20$ & 34 & 512 & 531 \\
\hline $6 / 20$ & 29 & 502 & 462 \\
\hline $7 / 20$ & 27 & 512 & 422 \\
\hline $8 / 20$ & 31 & 509 & 487 \\
\hline $9 / 20$ & 41 & 512 & 641 \\
\hline $10 / 20$ & 27 & 500 & 432 \\
\hline $11 / 20$ & 30 & 511 & 470 \\
\hline $12 / 20$ & 35 & 503 & 557 \\
\hline $13 / 20$ & 31 & 510 & 486 \\
\hline $14 / 20$ & 30 & 502 & 478 \\
\hline $15 / 20$ & 36 & 502 & 574 \\
\hline $16 / 20$ & 37 & 508 & 583 \\
\hline $17 / 20$ & 37 & 506 & 583 \\
\hline $18 / 20$ & 37 & 504 & 587 \\
\hline $19 / 20$ & 32 & 502 & 510 \\
\hline $20 / 20$ & 26 & 508 & 409 \\
\hline $21 / 20$ & 32 & 503 & 509 \\
\hline $22 / 20$ & 41 & 500 & 656 \\
\hline $23 / 20$ & 30 & 510 & 471 \\
\hline $24 / 20$ & 34 & 506 & 538 \\
\hline $25 / 20$ & 29 & 500 & 464 \\
\hline $26 / 20$ & 31 & 507 & 489 \\
\hline $27 / 20$ & 30 & 504 & 476 \\
\hline $28 / 20$ & 26 & 505 & 412 \\
\hline $29 / 20$ & 44 & 510 & 690 \\
\hline $30 / 20$ & 34 & 508 & 535 \\
\hline Rata- & rata Plasmodiun & $\mu \mathrm{l}$ darah & 518 \\
\hline
\end{tabular}

Berdasarkan tabel 4, diketahui kepadatan Plasmodium malaria tertinggi yaitu 690/ $\mu 1$ darah, pada sediaan darah dengan nomor kode 29/20, sedangkan terendah dengan jumlah $409 / \mu 1$ darah pada sediaan darah dengan nomor kode 20/20. Jumlah rata-rata Plasmodium malaria yang diperoleh pada tetes darah tebal dengan volume sampel $16 \mu$ l adalah 518/ $\mu$ l darah. 
Tabel 5. Hasil Rata - Rata Plasmodium Malaria dalam Variasi Volume Tetes Darah Tebal

\begin{tabular}{cc}
\hline Volume Darah $(\boldsymbol{\mu l})$ & $\begin{array}{c}\text { Rata - Rata } \\
\text { Plasmodium }\end{array}$ \\
\hline 6 & 393 \\
\hline 10 & 500 \\
\hline 16 & 636 \\
\hline 20 & 518 \\
\hline
\end{tabular}

Berdasarkan data tabel 3.5, terlihat ada peningkatan jumlah Plasmodium dari volume 6 $\mu \mathrm{l}$ sampai dengan $16 \mu \mathrm{l}$, namun pada volume 20 $\mu l$ terjadi penurunan jumlah.

\section{2) Analisa Bivariat}

Tabel 6. Perbedaan variasi volume sampel darah dengan volume sampel darah standar 6 $\mu 1$

\begin{tabular}{cccc}
\hline \multicolumn{2}{c}{$\begin{array}{c}\text { Variasi volume } \\
\text { sampel }\end{array}$} & $\begin{array}{c}\text { Perbedaan } \\
\text { Rerata }\end{array}$ & p value \\
\hline \multirow{3}{*}{$6 \mu 1$} & $10 \mu 1$ & -107.367 & 0.000 \\
\cline { 2 - 4 } & $16 \mu 1$ & -143.400 & 0.000 \\
\cline { 2 - 4 } & $20 \mu 1$ & -124.667 & 0.000 \\
\hline
\end{tabular}

Berdasarkan data tabel6, yang merupakan hasil Uji Anova diperoleh nilai $p=0.000<\alpha$ 0.005. Hal ini menunjukan $\mathrm{H}_{\mathrm{o}}$ ditolak dan $\mathrm{H}_{1}$ diterima, dengan demikian maka ada perbedaan antara variasi volume $10 \mu \mathrm{l}, 16 \mu \mathrm{l}, 20 \mu \mathrm{l}$ dengan volume standar $6 \mu \mathrm{l}$.

\section{Pembahasan}

Perhitungan jumlah Plasmodium malaria dari sediaan tetes darah tebal yang dibuat pada kaca sediaan, merupakan cara untuk menilai kepadatan Plasmodium dalam darah penderita dan dapat digunakan sebagai evaluasi atas pengobatan malaria, serta resistensi dari suatu jenis obat anti malaria.Sediaan darah tebal yang baik bila ditemukan 10 sampai 20 leukosit per lapangan pandang besar (LPB).

Pada penelitian ini sampel darah yang digunakan adalah pasien dengan positif mengandung Plasmodium malaria. Setelah mendapat sampel, peneliti membuat sediaan darah tetes tebal berbentuk bulat diameter $1 \mathrm{~cm}$ dengan variasi volume ; $6 \mu 1,10 \mu 1,16 \mu 1$ dan $20 \mu$ l. Dari beberapa teori menjelaskan bahwa 2-3 tetes darah yang digunakan setara dengan 6 $\mu \mathrm{l}$ dan terkandung didalamnya $10-20$ sel leukosit perlapang pandang. Cara ini masih dipakai oleh petugas malaria di lapangan dan di sarana kesehatan, terutama yang belum memiliki alat mikropipet. Menggunakan 2-3 tetes darah yang diambil di ujung jari sangat mudah dilakukan.. Yang masuk dalam hitungan peneliti adalah stadium tropozoit, sedangkan gametosit dan skizon tidak dihitung. Tropozoit ini menyebabkan pasien menderita demam, sehingga mudah ditemukan dalam aliran darah. Tropozoit muda dalam sediaan darah sering telihat dalam bentuk cincin, sedangkan stadium lanjut akan terlihat bervariasi berbentuk koma ataupun seperti burung terbang. Banyak tropozoit dalam darah tergantung dari spesies Plasmodium, karena masing - masing spesies akan menghasilkan jumlah merozoit yang berbeda, (Direktur Jenderal PP dan PL Kementrian Kesehatan. 2011).

Secara teori penggunaan darah tebal mempunyai kelebihan dimana sejumlah besar sel darah merah akan terhemolisis. Parasit yang ada terkonsentrasi pada area yang lebih kecil sehinga akan lebih cepat terlihat di bawah mikroskop dan dapat menemukan parasit lebih cepat karena volume darah yang digunakan lebih banyak. Jumlah parasit lebih banyak dalam satu lapang pandang, sehingga pada infeksi ringan mudah ditemukan.Sedangkan kelemahan dari darah tebal bentuk parasit yang kurang lengkap morfologinya.

Dari hasil penelitian dapat dilihat ada terjadi peningkatan rata-rata jumlah Plasmodium malaria dari setiap variasi volume, peningkatan ini setara dengan bertambahnya volume sampel darah yang digunakan. Hal ini perlu menjadi perhatian karena pada kenyataan masih banyak tenaga mikroskopis malaria yang menggunakan 2-3 tetes sampel darah untuk menghitung jumlah Plasmodium dalam darah. Penggunaan jumlah tetesan yang tidak tepat akan berpengaruh terhadap jumlah Plasmodium, dimana kedalaman tusukan dan pengaruh penekanan pada jari akan berdampak kepada hal tersebut.

Penggunaan mikropipet untuk pengukuran $6 \mu \mathrm{l}$ pada penelitian ini dapat mengukur rata-rata Plasmodium malaria sebanyak 393/ $\mu 1$ darah, namun dari hasil identifikasi terhadap sel leukosit yang dipakai sebagai pembanding dalam perhitungan tidak sesuai dengan teori yang menjelaskan bahwa volume $6 \mu \mathrm{l}$ akan mengandung besar adalah 10 s/d 20 leukosit/ lapang pandang besar, karena leukosit yang ditemukan kurang dari 10/ LPB. Hal ini menunjukan bahwa 2-3 tetes yang dipakai untuk sampel pemeriksaan tidak tepat.

Untuk volume $10 \quad \mu l$ sampel darah ditemukan rata-rata Plasmodium sebanyak 500, bila dibandingkan dengan $6 \mu$ l, maka pada 10 $\mu l$ terlihat ada peningkatan jumlahnya. Hasil identifikasi terhadap sel leukosit dijumpai perlapang pandang besar yakni : 10-15 leukosit. 
Hal ini menunjukan volume sampel yang digunakan berpengaruh terhadap jumlah komponen-komponen darah.

Volume $16 \mu \mathrm{l}$ sampel darah yang dipakai untuk menghitung Plasmodium menunjukan pening-katan jumlah yakni 636 Plasmodium/ $\mu 1$, bila dibandingkan dengan volume $6 \mu \mathrm{l}$ terlihat peningkatan jumlah rata-rata. Pada hal penggunaan 2-3 tetes sampel masih digunakan, bila dibandingkan dengan $16 \mu \mathrm{l}$, volume ini lebih mendekati ketelitiannya, dimana sel leukosit yang dihitung perlapang pandang ditemukan 15-20 sel. Pada volume ini eritrosit tidak lisis secara sempurna, sehingga tampak pada sediaan masih terlihat eritrosit. Hal ini dapat menyebabkan ada Plasmodium malaria didalamnya yang belum terbaca, bila terbaca maka jumlah Plasmodiumpun dapat meningkat.

Untuk volume sampel $20 \mu \mathrm{l}$ terlihat terjadi penurunan rata-rata Plasmodium menjadi $518 / \mu 1$ darah, dari volume $16 \mu$ l dengan jumlah rata-rata Plasmodium 636, namun masih lebih tinggi dari jumlah rata-rata Plasmodium pada volume $6 \mu \mathrm{l}$ dengan jumlah rata-rata $393 \mu \mathrm{l}$. Penurunan jumlah ini dapat disebabkan oleh proses lisisnya eritrosit yang tidak sempurna sehingga masih banyak Plasmodium yang terperangkap dalam eritrosit. Hasil identifikasi terhadap Plasmodium pada volume $20 \mu 1$ sangat terlihat jelas selain dari eritrosit tidak lisis dengan sempurna, juga Plasmodium tidak terwarnai dengan sempurna, sehingga inti tidak berwarna merah tegas dan sitoplasma juga tidak berwarna biru.

Proses lisis yang tidak sempurna dari volume sampel darah $16 \mu \mathrm{l}$ dan $20 \mu \mathrm{l}$ ini dapat disebabkan oleh diameter bulatan yang merupakan standar WHO dan Kementerian Kesehatan RI yakni: $1 \mathrm{~cm}$. Diameter seperti ini dapat menyebabkan eritrosit akan menumpuk sehingga pada proses pewarnaan eritrosit yang berada pada bagian paling dasar yang menempel pada kaca sediaan akan tidak mengalami proses hemolisis dengan sempurna dan komponen Plasmodium juga tidak menyerap zat pewarna dengan maksimal walaupun menggunakan waktu 60 menit.

Makin banyak Plasmodium dalam darah pasien atau responden menandakan makin tinggi tingkat infeksi, untuk itu ketepatan dalam pengukuran sangat penting. Evaluasi keberhasilan dalam penanganan malaria dapat dipengaruhi oleh tindakan seorang tenaga mikroskopis malaria mulai dari pra-analitik sampai dengan pasca analitik.

Pengukuran dengan menggunakan mikropipet sangat baik untuk mengurangi kesalahan peneliti dalam pengambilan sampel, sehingga hasil yang didapatkan memiliki nilai kebenaran yang tinggi. Perlu diketahui penggunaan volume yang kita gunakan makin kecil, maka sumber kesalahan makin besar. Untuk itu penggunaan mikropipet harus sesuai dengan standar operasinal prosedur, sehingga volume yang diambil sesuai dengan kebutuhan.

Adapun kendala dalam penelitian ini adalah untuk mendapatkan sampel, hal ini karena pemerintah dalam hal ini Kementerian Kesehatan lagi menggalakan eliminasi malaria, dan Provinsi Maluku Utara merupakan salah satu provinsi di Wilayah Indonesia Timur yang bertekad untuk menunjang program eliminasi ini, sehingga makin sedikit penderita malaria yang datang ke RSUD dr.H. Chasan Boesoirie Ternate.

Berdasarkan hasil penelitian yang telah diperoleh, maka disimpulkan sebagai berikut:

1. Ada perbedaan yang signifikan antara volume standar $6 \mu$ l dengan variasi volume $10 \mu \mathrm{l}, 16 \mu \mathrm{l}$ dan $20 \mu \mathrm{l}$ setelah data penelitian dianalisa menggunakan uji Anova.

2. Makin besar jumlah volume darah yang digunakan untuk sediaan darah tebal makin meningkat jumlah Plasmodium malaria.

3. Sediaan darah tebal dengan volume $6 \mu 1$ dapat dipakai untuk mengidentifikasi Plasmodium dengan baik, namun untuk jumlah sel leukosit tidak mencapai 10 /LPB sesuai teori.

4. Sediaan darah tebal dengan volume $10 \mu \mathrm{l}$ dapat mengidentifikasi dan menghitung jumlah Plasmodium dengan baik dan sel leukosit mencapai 10-20 /LPB sesuai standar.

5. Penyerapan zat pewarna Giemsa tidak maksimal pada sediaan darah tebal dengan volume $16 \mu \mathrm{l}$ dan $20 \mu \mathrm{l}$, disebabkan oleh ketebalan dari sediaan darah, sehingga dimungkinkan ada Plasmodium yang tidak teridentifikasi.

Saran pada penelitian ini adalah :

1. Penggunaan volume minimal $10 \mu \mathrm{l}$ darah untuk pembuatan sediaan darah tebal cukup baik, agar dapat mengidentifikasi Plasmodium malaria dan menghitung jumlah sel leukosit dengan baik.

2. Tidak menggunakan volume $16 \mu 1$ dan 20 $\mu \mathrm{l}$ sediaan darah tebal untuk pewarnaan dengan konsentrasi 3\% dengan lama waktu 60 menit, karena ada sel eritrosit yang tidak lisis dengan sempurna.

3. Penggunaan mikropipet sangat baik untuk pengukuran dalam bekerja karena memiliki ketelitian yang tinggi dibandingkan dengan 
penggunaan 2-3 tetes darah yang tidak tau pasti volumenya.

4. Peneliti selanjutnya dapat menggunakan volume minimal $10 \mu \mathrm{l}$ dan maksimal $14 \mu \mathrm{l}$ sampel darah untuk melihat Plasmodium malaria dan jumlah sel leukosit perlapang pandang besar.

\section{Daftar Pustaka}

Arny. 2019. Mikropipet: pipet akurat dalam penelitian. Diakses dari: https://www.medicalogy.com/blog/mikro pipet-pipet-akurat-dalam-penelitian/

Direktur Jenderal PP dan PL Kementrian Kesehatan.2011, "Pedoman Teknis Pemeriksaan Parsit Malaria”, Kementrian Kesehatan, Jakarta

Direktur Jenderal PP dan PL Kementrian Kesehatan.2014, "Pedoman Teknis Pemeriksaan Malaria", Kementrian Kesehatan,Jakarta

Rosdiana Safar, 2010, "Parasitologi Kedokteran Protozologi, Helmintologi, Entomologi “ edisi khusus, Yrama Widya, Bandung.

Soedarto, Prof. Dr DTM\&H,PhD, 2011,"Buku Ajar Parasitologi Kedokteran", Sagung Seto, Surabaya. 